\title{
Labile and Non-Labile Fractions of Phosphorus and Its Transformations in Soil under Eucalyptus Plantations, Brazil
}

\author{
Marlon Gomes Costa ${ }^{1}$, Antonio Carlos Gama-Rodrigues 1,*, \\ José Leonardo de Moraes Gonçalves ${ }^{2}$, Emanuela Forestieri Gama-Rodrigues ${ }^{1}$, \\ Marcus Vinicius da Silva Sales ${ }^{1}$ and Seldon Aleixo ${ }^{1}$ \\ Received: 5 October 2015; Accepted: 21 December 2015; Published: 6 January 2016 \\ Academic Editor: Eric J. Jokela \\ 1 UENF, Laboratório de Solos, Universidade Estadual do Norte Fluminense Darcy Ribeiro, \\ Campos dos Goytacazes CEP 28013-602, Brazil; marlong@uenf.br (M.G.C.); emanuela@uenf.br (E.F.G.-R.); \\ msales@uenf.br (M.V.S.S.); seldon_aleixo@mail.com (S.A.) \\ 2 USP, Departamento de Ciências Florestais , Universidade de São Paulo, ESALQ, Piracicaba CEP 13418-900, \\ Brazil; jlmgonca@usp.br \\ * Correspondence: tonygama@uenf.br; Tel.: +55-22-2748-6514
}

\begin{abstract}
Phosphorus (P) is the main limiting nutritional factor in the cultivation of Eucalyptus in Brazil. Despite this, little is known about the P fractions and dynamics in Eucalyptus soils in tropical regions. The aims of this study were (1) to evaluate the distribution of labile and non-labile fractions of $\mathrm{P}$ in soil in 10 sites of Eucalyptus in the state of São Paulo, Brazil and (2) to determine the interactions among the $\mathrm{P}$ fractions and to identify which fractions act as sinks or sources for the available $\mathrm{P}$ fraction. The $P$ fractions were separated using the Hedley sequential extraction method, and the $P$ transformation processes were evaluated via structural equation modeling. The labile $\mathrm{P}$ (resin-Pi $+\mathrm{Pi}$ and $\mathrm{Po}$ in $\mathrm{NaHCO}_{3}$ ) varied between $6 \%$ and $16 \%$, the moderately labile $\mathrm{P}(\mathrm{Pi}+\mathrm{Po}$ in $\mathrm{NaOH})$ varied between $28 \%$ and $40 \%$, the occluded $\mathrm{P}(\mathrm{Pi}+\mathrm{Po}$ in Sonicate $+\mathrm{NaOH})$ varied between $6 \%$ and $19 \%$, the $\mathrm{P}$ associated with $\mathrm{Ca}(\mathrm{HCl}-\mathrm{Pi})$ varied between $0.4 \%$ and $3 \%$ and the residual-P varied between $35 \%$ and $47 \%$. The hypothetical structural model of soil P cycle was composed of four P pools (latent variables): the organic pool, occluded pool, inorganic pool, and available pool. The structural model was adequate to identify functional pools of $\mathrm{P}$ in soil, and to identify transformation processes of $\mathrm{P}$ based on the source-sink relationships. The available P pool was highly dependent on inorganic and occluded pools and the organic pool acted predominantly as a sink of $\mathrm{P}$ on available and inorganic pools. The results reinforce the high level of recalcitrance of the organic pool and the fact that Eucalyptus plants must access pools of limited-availability $\mathrm{P}$ to meet their nutritional demands.
\end{abstract}

Keywords: tropical forest soils; organic P pool; inorganic P pool; occluded P pool; structural equation modeling

\section{Introduction}

Eucalyptus represents more than 20 million hectares grown over more than 90 countries [1] and has played an increasingly important role in satisfying global demand for wood products. Now, it accounts for $8 \%$ of cultivated forest worldwide, with a third of this found in the tropics [2]. Brazil has 7.6 million hectares of cultivated forests, of which $72 \%$ are in the Eucalyptus genus, and account for $17 \%$ of the harvested wood worldwide [3]. Characteristics of Eucalyptus genus such as rapid growth, high productivity and adaptability to varying soil and climate conditions, tolerance to acidity, toxicity to $\mathrm{Al}$ and low base saturation, explain such a high proportion of total cultivation in forests both in Brazil and elsewhere. 
The initial stages of cultivation usually involve mineral fertilization, and responses to $\mathrm{P}$ applications are often of a high magnitude [4]. The exploitation of low natural fertility soils, such as those in the Brazilian Cerrado, has increased, thus exposing the soils' nutritional limitations. These limitations, particularly of nutrients $\mathrm{P}, \mathrm{K}$ and B, are common in Eucalyptus cultivation [5]. Nowadays, fertilization is responsible for gains of between $30 \%$ and $50 \%$ in wood production. $\mathrm{P}$, besides being a minor macronutrient in plants, has a significant impact on wood productivity [3].

Well-known for limiting the primary productivity of natural tropical forests [6], $\mathrm{P}$ is also the main limiting nutritional factor in the development of forest cultivation of Eucalyptus in Brazil. This problem occurs mainly in highly weathered soils, like most tropical and subtropical areas, and is characterized by a low content of total $\mathrm{P}$ and available $\mathrm{P}$, and with high $\mathrm{P}$ fixation capacities. Phosphorus is found in soils in inorganic forms (Pi) and organic forms (Po) and according to the degree of stability or solubility, these allow different bioavailability of P. Pi can be found in solution (P-solution) and fixed through the adsorption phenomenon, with oxides of $\mathrm{Fe}$ and $\mathrm{Al}$ (of clay fraction). This process establishes either weak adsorption (labile $\mathrm{P}$ ) or strong adsorption (moderately labile $\mathrm{P}$ ) with these oxides and, precipitated with $\mathrm{Al}, \mathrm{Fe}$ and $\mathrm{Ca}$, establishes insoluble forms (non-labile $\mathrm{P}$ ) [7]. Po is formed by phosphate ions, which are bonded to $\mathrm{C}$ moieties and its lability is directly related to the decomposition susceptibility of the organic moiety to which the phosphate is bonded [8]. In natural systems or in soils with little or no $\mathrm{P}$ addition, the element availability is directly related to the organic forms cycling [9-11]. Thus the soil can be a source of $P$, while providing stocks of available $P$ to plants or a P sink when part of the added fertilizer is fixed. This leads to competition between plants and soils for the available P.

The complex dynamics of this nutrient in tropical conditions validates other studies about the relationships between fractions, which aim to enhance knowledge of the $P$ transformations that occur in these soils. Hedley et al. [12] developed a method of sequential extraction or fractionation of $\mathrm{P}$ that characterizes different organic and inorganic fractions of $P$ from soil based on solubility of inorganic and organic $P$. This method has been widely applied since then and has become almost standard to characterize $P$ forms in soils [13]. It enables us to distinguish labile from non-labile fractions and to rank stable fractions and organic fractions by availability to plants. Based on this extraction, $\mathrm{P}$ can be classified as available to plants or microorganisms (labile $\mathrm{P}$ ), which includes the sum of $\mathrm{Pi}$ and Po extracted in resin and bicarbonate. The refractory forms or non-labile $\mathrm{P}$ include the sum of remaining fractions ( $\mathrm{Pi}$ and $\mathrm{Po}$ in hydroxide and in sonicate + hydroxide, $\mathrm{Pi}$ in $\mathrm{HCl}$ and residual $\mathrm{P}$ in sulfuric digestion) [14]. In a review on the use of the Hedley method, contrasting agroecosystems of tropical and temperate climates, with different soil use and managements, Negassa and Leinweber [15] reported that inorganic and organic fractions of $\mathrm{P}$ could act as a source or sink of available P to plants, as a result of several factors such as climate, soil management and mineral fertilization.

Although some literature supports the potential of the Hedley method in studies that involve the dynamics of $P$ in soil [16-21], there are few studies into tropical soil in Eucalyptus plantations. In general, the management of soil fertility for estimating the available P in Eucalyptus plantations in Brazil has been based only on $\mathrm{P}$ acid extraction (Mehlich-1 P) [22] or resin-extracted [5] and has not considered other $\mathrm{P}$ forms in the soil that may be $\mathrm{P}$ sources for plants. The aims of this study were (1) to evaluate the distribution of labile and non-labile fractions of $\mathrm{P}$ in soil in 10 sites of Eucalyptus in the state of São Paulo, Brazil and (2) to build a hypothetical structural model of the P cycle in soil to determine the interactions among the $\mathrm{P}$ fractions and to identify which fractions act as a sink or source of the available $P$ fraction.

\section{Material and Methods}

\subsection{Study Sites}

In order to conduct this study, 10 sites forested with Eucalyptus grandis Hill (ex Maiden) and Eucalyptus grandis $\times$ E. urophylla S.T. Blake clonal hybrid were selected in the state of São Paulo, with 
ages varying from 1.4 to 11 years, all of which are managed with minimum cultivation. The sites belong to forestry companies in São Paulo state and to the Department of Forestry Science of ESALQ/USP and are located in different regions (Table 1).

The sites are located at altitudes from $570 \mathrm{~m}$ to $889 \mathrm{~m}$. According to the Köppen classification, climates correspond to types: Aw (Agudos and Altinópolis) and Cwa (Angatuba, Botucatu, Capão Bonito, Itatinga, São Miguel Arcanjo, Paraíbuna and Votorantim). In accordance with EMBRAPA (1999) [23], the soils were classified as Dystrophic Red Yellow Latosol (Oxisol) (Itatinga, São Miguel Arcanjo and Paraíbuna), Quartzarenic Neosol (Entisol) (Altinópolis, Angatuba and Botucatu), Dystrophic Red Latosol (Oxisol) (Agudos and Capão Bonito 2), Dystrophic Yellow Latosol (Oxisol) (Capão Bonito 1), Dystrophic Red Yellow Argisol (Ultisol) (Votorantim) and Dystrophic Haplic Cambisol (Inceptisol) (Capão Bonito 3) (Table 1). These are the main soils used in afforestation in São Paulo state [4].

In all sites, the forest plantations were established using a minimum cultivation system with the maintenance of plant residues (litter and harvest residues) on soil, followed by soil preparation in planting rows. At each site, three fixed plots were installed. The plots consisted of different plant densities on each site (Table 1). For the purposes of this study, sample plots were not fertilized with $P$ and soil sampling was conducted $1.5 \mathrm{~m}$ away from the row planting.

\subsection{Physical-Chemical Characterization of Soil}

On each site in 2010, ten single soil samples were collected in order to form a composite sample at depths of $0-20 \mathrm{~cm}$ in each plot (three plots per site). The samples were collected in a diagonal transect to a representative area of plots between the row planting. It was assumed that with this sampling procedure, there was no influence from fertilization in planting holes conducted at the sites. The soil samples were air-dried, homogenized, prepared and passed through $2 \mathrm{~mm}$ sieves. These samples were used for physical and chemical characterizations and determination of $P$ fractions. Table 2 displays physical and chemical characterizations and demonstrates that the sites presented great variability in such properties [23]. The soils were characterized as very acidic, the levels of P Mehlich-1, exchangeable $\mathrm{K}$ and $\mathrm{Ca}$ are considered low in most of the sites, and levels of exchangeable Mg were satisfactory in all sites, based both on an average annual increment of wood equal to $50 \mathrm{~m}^{3} \cdot \mathrm{ha}^{-1} \cdot$ year $^{-1}$ and on nutritional levels considered critical in Eucalyptus plantations [22]. The low level of exchangeable bases and high potential acidity resulted in levels of base saturation $(\mathrm{V})$ bellow the ideal $(30 \%)$, in most of the sites and the saturation by aluminum (m) within the maximum acceptable for Eucalyptus (45\%), in most sites [24].

\subsection{Soil P Fractions}

The P fractions of soil were sequentially extracted according to the Hedley method [12], which separates $\mathrm{P}$ of soil into five inorganic fractions, three organic and one residual. The fractionation was done with resin membrane (available $\mathrm{Pi}$ ), $\mathrm{NaHCO}_{3}$ (labile $\mathrm{Pi}$ and $\mathrm{Po}$ adsorbed on the soil surface), $\mathrm{NaOH}$ (moderately labile Pi and Po held more strongly by chemisorption to surfaces of $\mathrm{Al}$ and $\mathrm{Fe}$ oxides), Sonicate $+\mathrm{NaOH}$ ( $\mathrm{Pi}$ and $\mathrm{Po}$ adsorbed within surfaces of $\mathrm{Al}$ and $\mathrm{Fe}$ oxides of soil aggregates—occluded $\mathrm{P}$ ), $\mathrm{HCl}$ ( $\mathrm{P}$ associated to $\mathrm{Ca}$, derived from primary mineral-apatite) and a digestion with $\mathrm{H}_{2} \mathrm{SO}_{4}+\mathrm{H}_{2} \mathrm{O}_{2}$ (residual $\mathrm{P}$-non-labile; stable Po forms and relatively insoluble Pi forms). 
Table 1. Sites, species, plant density, climate types, soil orders, soil texture and age in Brazilian Eucalyptus plantations.

\begin{tabular}{|c|c|c|c|c|c|c|c|c|c|c|}
\hline Site * & Species & Density (m) & $\operatorname{Plot}\left(\mathrm{m}^{2}\right)$ & $\begin{array}{c}\text { Plants } \\
\text { per Plot }\end{array}$ & Climate $^{(1)}$ & $\mathrm{T}\left({ }^{\circ} \mathrm{C}\right)$ & $\begin{array}{l}\text { Precipitation } \\
(\mathrm{mm})\end{array}$ & Soil ${ }^{(2)}$ & Soil Texture & Age (Years) \\
\hline AG & Eucalyptus grandis (G-232) & $3.0 \times 2.0$ & 144 & 24 & Aw & 21.6 & 1170 & $\mathrm{LVd}$ & loam & 3.0 \\
\hline ANG & E. grandis $\times$ E. urophylla & $3.0 \times 2.0$ & 216 & 36 & Cwa & 20.6 & 1262 & $\mathrm{RQ}$ & sandy & 2.0 \\
\hline BOT & E. grandis (G-232) & $3.0 \times 2.0$ & 144 & 24 & Cwa & 20.2 & 1302 & RQ & sandy & 3.0 \\
\hline ITA & E. grandis (Suz.) & $3.0 \times 2.0$ & 144 & 24 & Cwa & 19.9 & 1308 & LVAd & loam & 4.0 \\
\hline $\operatorname{ALT}^{(3)}$ & E. grandis $\times$ E. urophylla & $3.0 \times 2.5$ & 180 & 24 & Aw & 20.7 & 1517 & $\mathrm{RQ}$ & sandy & 7.0 \\
\hline CB1 ${ }^{(4)}$ & E. grandis $\times$ E. urophylla & $3.0 \times 3.0$ & 360 & 40 & Cwa & 20.1 & 1210 & LAd & clayey & 9.0 \\
\hline CB2 (5) & E. grandis $\times$ E. urophylla & $3.0 \times 2.0$ & 144 & 24 & Cwa & 20.1 & 1210 & $\mathrm{LVd}$ & very clayey & 1.4 \\
\hline $\mathrm{CB} 3^{(6)}$ & E. grandis $\times$ E. urophylla & $3.0 \times 2.0$ & 144 & 24 & Cwa & 20.1 & 1210 & CXBd & loam & 1.6 \\
\hline $\mathrm{PA}^{(7)}$ & E. grandis (Parb.) & $3.0 \times 2.5$ & 180 & 24 & Cwa & 20.8 & 1249 & LVAd & clayey & 11.0 \\
\hline VOT $^{(8)}$ & E.grandis $\times$ E. urophylla & $3.0 \times 2.0$ & 96 & 16 & Cwa & 21.3 & 1287 & PVAd & very clayey & 1.8 \\
\hline
\end{tabular}

* AG-Agudos, ANG—Angatuba, BOT—Botucatu, ITA-Itatinga, ALT—Altinópolis, CB1—Capão Bonito 1, CB2—Capão Bonito 2, CB3-Capão Bonito 3, PA—Paraibuna, VOT-Votorantim. ${ }^{(1)}$ Aw means tropical climate with dry winter season and temperature in the coldest month of the year exceeding $18{ }^{\circ} \mathrm{C}$ and Cwa means humid temperate climate with dry winter and hot summer. ${ }^{(2)}$ According to Brazilian System of Soil Classification (EMBRAPA 1999): LVd = Latossolo Vermelho distrófico (Oxisol), RQ = Neossolo Quartzarênico (Entisol), LAd = Latossolo Amarelo distrófico (Oxisol), CXBd = Cambissolo Háplico distrófico (Inceptisol), LVAd = Latossolo Vermelho-Amarelo distrófico (Oxisol), PVAd = Argissolo Vermelho-Amarelo distrófico (Ultisol). Six sites received NPK fertilization at planting: (3) $123 \mathrm{~kg} \cdot \mathrm{ha}^{-1}$, (4) $290 \mathrm{~kg} \cdot \mathrm{ha}^{-1}$, (5) $183 \mathrm{~kg} \cdot \mathrm{ha}^{-1}$, (6) $183 \mathrm{~kg} \cdot \mathrm{ha}-1$, (7) $120 \mathrm{~kg} \cdot \mathrm{ha}{ }^{-1}$, and (8) $183 \mathrm{~kg} \cdot \mathrm{ha}^{-1}$ of the formula 04-28-06. The sites AG and BOT received fertilization applying $15 \mathrm{~kg} \cdot \mathrm{ha}^{-1}$ of N and $\mathrm{K}_{2} \mathrm{O}, 18 \mathrm{~kg} \cdot \mathrm{ha}{ }^{-1}$ of N and $\mathrm{K}_{2} \mathrm{O}$, respectively, besides $13 \%$ of $\mathrm{S}$ and $10 \%$ of $\mathrm{B}$, at each site. Supplementary fertilization was also held at planting with other elements to the sites $\mathrm{CB} 1(0.3 \%$ of $\mathrm{B}), \mathrm{CB} 2(10 \%$ of $\mathrm{Ca}, 4 \%$ of $\mathrm{S}, 0.3 \%$ of $\mathrm{Cu}$ and $0.7 \%$ of $\mathrm{Zn}), \mathrm{CB} 3$ $(10 \%$ of $\mathrm{Ca}, 4 \%$ of $\mathrm{S}, 0.3 \%$ of $\mathrm{Cu}$ and $0.7 \%$ of $\mathrm{Zn}), \mathrm{PA}(2.4 \%$ of $\mathrm{Mg})$ and VOT ( $10 \%$ of $\mathrm{Ca}, 4 \%$ of $\mathrm{S}, 0.3 \%$ of $\mathrm{Cu}$ and $0.7 \%$ of $\mathrm{Zn}$ ). Still was held cover fertilization on the sites $\mathrm{CB} 1$ at 3 and 9 months ( $8 \mathrm{~kg} \cdot \mathrm{ha}^{-1}$ of $\left.\mathrm{B}\right) ; \mathrm{CB} 2$ at 3 months ( $41 \mathrm{~kg}$ of $\mathrm{K}_{2} \mathrm{O}$ and $1.5 \%$ of B), at 6 months $\left(\sim 36 \mathrm{~kg}\right.$ of $\mathrm{K}_{2} \mathrm{O}, 0.5 \%$ of B and $1 \%$ of $\left.\mathrm{Zn}\right)$ and at $12 \mathrm{months}\left(\sim 35 \mathrm{~kg}\right.$ of $\mathrm{K}_{2} \mathrm{O}, 0.7 \%$ of B and $1 \%$ of $\mathrm{Zn})$; CB3 at 3 months ( $\sim 40 \mathrm{~kg}$ of $\mathrm{K}_{2} \mathrm{O}$ and $1.5 \%$ of $\left.\mathrm{B}\right)$, at 6 months ( $75 \mathrm{~kg}$ of $\mathrm{K}_{2} \mathrm{O}, 0.5 \%$ of B and $1 \%$ of $\left.\mathrm{Zn}\right)$ and at 12 months $\left(\sim 60 \mathrm{~kg}\right.$ of $\mathrm{K}_{2} \mathrm{O}, 0.7 \%$ of $\mathrm{B}$ and $1 \%$ of $\left.\mathrm{Zn}\right)$; and VOT at 3 months ( $\sim 41 \mathrm{~kg}$ of $\mathrm{K}_{2} \mathrm{O}$ and $0.3 \%$ of $\mathrm{B}$ and $1 \%$ of $\mathrm{Zn}$ ) and at 9 months $\left(\sim 126 \mathrm{~kg}\right.$ of $\mathrm{K}_{2} \mathrm{O}$ and $1.5 \%$ of $\left.\mathrm{B}\right)$ 
Table 2. Physical and chemical attributes of soils $(0-20 \mathrm{~cm})$ under Brazilian Eucalyptus plantations.

\begin{tabular}{|c|c|c|c|c|c|c|c|c|c|c|}
\hline \multirow{2}{*}{ Site * } & Clay & C & $P^{1}$ & $\mathrm{pH}$ & $\mathrm{K}$ & $\mathrm{Ca}$ & Mg & CEC & \multirow{2}{*}{$\frac{\text { Al sat. }}{\%}$} & \multirow{2}{*}{$\begin{array}{l}\text { BS } \\
\%\end{array}$} \\
\hline & $\mathbf{g} \cdot \mathbf{k g}^{-1}$ & $\mathrm{~g} \cdot \mathrm{dm}^{-3}$ & $\mathbf{m g} \cdot \mathbf{k g}^{-1}$ & $\mathrm{CaCl}_{2}$ & \multicolumn{4}{|c|}{$\mathrm{mmol}_{\mathbf{c}} \cdot \mathrm{dm}^{-3}$} & & \\
\hline AG & 167 & 12.2 & 4.0 & 3.9 & 4.8 & 4.8 & 2.4 & 70.7 & 52.2 & 17 \\
\hline ANG & 100 & 10.4 & 8.5 & 4.0 & 0.6 & 5.0 & 2.5 & 47.0 & 44.5 & 17 \\
\hline BOT & 100 & 8.7 & 8.3 & 4.0 & 0.4 & 4.0 & 5.0 & 49.5 & 36.9 & 25 \\
\hline ITA & 193 & 11.0 & 2.4 & 2.6 & 0.9 & 2.1 & 2.4 & 65.6 & 67.8 & 8 \\
\hline ALT & 67 & 11.6 & 6.2 & 4.3 & 0.3 & 11.0 & 4.0 & 58.0 & 20.7 & 28 \\
\hline CB1 & 478 & 16.2 & 1.4 & 3.9 & 1.2 & 1.7 & 2.3 & 94.9 & 78.2 & 5 \\
\hline CB2 & 653 & 20.3 & 1.4 & 4.4 & 2.7 & 15.2 & 9.3 & 107.3 & 31.8 & 25 \\
\hline CB3 & 272 & 12.8 & 3.5 & 4.1 & 1.4 & 9.9 & 9.5 & 102.5 & 43.9 & 21 \\
\hline PA & 365 & 12.2 & 2.1 & 4.1 & 1.9 & 6.8 & 4.2 & 58.0 & 33.8 & 22 \\
\hline VOT & 670 & 29.0 & 2.2 & 4.0 & 5.0 & 5.0 & 2.1 & 125.6 & 58.4 & 9 \\
\hline
\end{tabular}

* AG-Agudos, ALT-Altinópolis, CB1-Capão Bonito 1, CB2-Capão Bonito 2, CB3-Capão Bonito

3, ITA-Itatinga, PA-Paraibuna, VOT-Votorantim, ANG-Angatuba, BOT-Botucatu; ${ }^{1}$ P Mehlich-1; $\mathrm{CEC}$-cation exchange capacity at $\mathrm{pH}$ 7.0; Al sat.-aluminum saturation = (exchange $\mathrm{Al} / \mathrm{CEC}) 100$; BS-base saturation.

The sequential separation of fractions of inorganic $\mathrm{P}(\mathrm{Pi})$ followed the order: (1) resin-Pi-extracted with $10 \mathrm{~mL}$ of deionized water and a resin membrane $(1 \times 5 \mathrm{~cm}$, ANION 204UZRA, Renics, São Paulo, Brazil) in a horizontal agitator (Tecnal, São Paulo, Brazil)at $120 \mathrm{rpm}$ per $16 \mathrm{~h}$. Afterwards, the resin was removed and placed in a falcon tube of $15 \mathrm{~mL}, 10 \mathrm{~mL}$ of $\mathrm{HCl} 0.5 \mathrm{~mol} \cdot \mathrm{L}^{-1}$ was added and then, after agitation and repose, the extract was used to determine P. (2) $\mathrm{NaHCO}_{3}-\mathrm{Pi}$-soil from the previous stage was centrifuged at $6000 \mathrm{rpm}$ for 20 mins and the supernatant was discharged, then $10 \mathrm{~mL}$ of extractor $\mathrm{NaHCO}_{3} 0.5 \mathrm{~mol} \cdot \mathrm{L}^{-1}$ at $\mathrm{pH} 8.5$ was added, followed by agitation for $16 \mathrm{~h}$ in a horizontal agitator at $120 \mathrm{rpm}$. Shortly after, the extract was centrifuged at $6000 \mathrm{rpm}$ for $20 \mathrm{mins}$, the supernatant was put aside (extract), and later more $5 \mathrm{~mL}$ of $\mathrm{NaCl} 0.5 \mathrm{~mol} \cdot \mathrm{L}^{-1}$ was added to the extract, derived from agitation at $6000 \mathrm{rpm}$ for 5 mins, which produced the final volume. (3) $\mathrm{NaOH}-\mathrm{Pi}$ was extracted with $10 \mathrm{~mL}$ of $\mathrm{NaOH} 0.1 \mathrm{~mol} \cdot \mathrm{L}^{-1}$ and followed the same subsequent stages used in extraction with bicarbonate; (4) Sonic-Pi (Sonicate $+\mathrm{NaOH}$ )—extracted with $10 \mathrm{~mL}$ of $\mathrm{NaOH} 0.1 \mathrm{~mol} \cdot \mathrm{L}^{-1}$ following the same subsequent stages used in the previous extraction. However the samples in falcon tubes of $15 \mathrm{~mL}$ were subjected to ultrasonification for 2 mins (model: USC-1800A, frequency US: $40 \mathrm{KHz}$, power US: $153 \mathrm{~W}$; Tecnal, São Paulo, Brazil), before agitation of 16 h. (5) Pi-HCl—extracted with addition of $10 \mathrm{~mL}$ of $\mathrm{HCl} 1.0 \mathrm{~mol} \cdot \mathrm{L}^{-1}$ following the same stages with agitation and centrifugation applied for bicarbonate; (6) In the remaining soil, after all extractions, digestion was conducted $\mathrm{H}_{2} \mathrm{SO}_{4}+\mathrm{H}_{2} \mathrm{O}_{2}$, at $200{ }^{\circ} \mathrm{C}$, to determine the residual $\mathrm{P}$ fraction. In order to determine total $\mathrm{P}(\mathrm{Pt})$ in extracts of $\mathrm{NaHCO}_{3} 0.5 \mathrm{~mol} \cdot \mathrm{L}^{-1}$, $\mathrm{NaOH} 0.1 \mathrm{~mol} \cdot \mathrm{L}^{-1}$ and sonicate $+\mathrm{NaOH} 0.1 \mathrm{~mol} \cdot \mathrm{L}^{-1}$, an aliquot was taken out and $1 \mathrm{~mL}$ of $\mathrm{H}_{2} \mathrm{SO}_{4}$ $24 \mathrm{~mol} \cdot \mathrm{L}^{-1}$ was added and $10 \mathrm{~mL}$ of $\left(\mathrm{NH}_{4}\right)_{2} \mathrm{~S}_{2} \mathrm{O}_{8}$ at $7.5 \%$ that was autoclaved at $121^{\circ} \mathrm{C}$ and $103 \mathrm{kPa}$ for $3 \mathrm{~h}$. After cooling, the volume was increased to $20 \mathrm{~mL}$ with distilled water. In extracts derived from different extractions, fractions of $\mathrm{Pi}$ and residual $\mathrm{P}$ were determined by the colorimetric method of Murphy and Riley [25] after adjusting the $\mathrm{pH}$, using $p$-nitrophenol as an indicator. Regarding Pt fractions, the determination was carried out using the colorimetric method of Dick and Tabatabai [26]. The organic $\mathrm{P}$ was calculated through the difference between the concentration of $\mathrm{Pt}$ and $\mathrm{Pi}$ in each extract $(\mathrm{Po}=\mathrm{Pt}-\mathrm{Pi})$. The organic fractions were denominated $\mathrm{NaHCO}_{3}-\mathrm{Po}, \mathrm{NaOH}-\mathrm{Po}$ and Sonic-Po.

\subsection{Statistical Analysis}

Each Eucalyptus site was considered to be a fixed-effect treatment due to several sources of variation, such as soil orders and management practices (Table 1). Thus, the data was subjected to the Kolmogorov-Smirnov and Lilliefors normality test and homoscedasticity and normal distribution residuals, which evaluates the normal distribution of analyzed variables. In sequence, the data regarding the $\mathrm{P}$ fractions were then submitted to principal component analysis (PCA), which allowed 
clustering of the sites evaluated in diagrams that consider the similarity of the data set of the variables along ordination axes, thus seeking associations of the P fractions among Eucalyptus sites [27].

The data were also analyzed using one-way analysis as well as the Scott-Knott test to group the means among the Eucalyptus sites, at 5\% probability. In each Eucalyptus site, the three plots were treated as pseudo-replication and were separated by at least several hundred meters from each other. Pseudo-replication is a limitation of the present study, as in many other Eucalyptus studies in paired sites and in chronosequences $[28,29]$. The relationships between all of the $\mathrm{P}$ fractions and the physical and chemical attributes of the soil were measured using the Pearson correlation coefficient. The program SAEG 9.1 (SAEG Inst. Inc., Viçosa, Brazil) was employed to conduct all statistical analysis.

Structural equation modeling (SEM) was applied to build a model of the P cycle, to identify interactions among $\mathrm{P}$ fractions and to identify which fractions acted as a sink or source of available P. For general fitting, the Chi-square test $\left(X^{2}\right)$ was employed. Due to the high sensitivity of this test in terms of sample size, the indexes of goodness of fit (GFI), comparative fit (CFI) and root mean squared error of approximation (RMSEA) were also considered as measurement alternatives. The Maximum Likelihood method was used for estimation of parameters. The analyses of SEM were conducted with the aid of the program AMOS, version 22 (IBM-SPSS Inc., Chicago, IL, US).

\section{Results}

\subsection{Distribution of Organic and Inorganic P Fractions}

High dissimilarity was observed among the forest sites based on PCA (Figure 1). In the PCA, the direction and length of the arrows show the degree of correlation between fractions and the principal components ( $X$ and $Y$ axes). The arrows that correspond to the $P$ fractions with low angles are strongly correlated, whereas the arrows that are perpendicular indicate absence of correlation. Three significant components were obtained (auto values $>1$; factorial loading $\geqslant 0.70$ in the first component). Only the two first components were used in order to facilitate interpretation of the bi-dimensional graph because component 3 constituted less than $7 \%$ of the total data variance. Thus, seven distinct groups were established. The sites ALT (Altinópolis) and BOT (Botucatu), AG (Agudos) and ITA (Itatinga), CB3 (Capão Bonito 3) and PA (Paraibuna) constituted the different groups. The sites ANG (Angatuba), VOT (Votorantim), CB1 (Capão Bonito 1) and CB2 (Capão Bonito 2) did not present similarity with any other site. The components $1(45 \%)$ and $2(26 \%)$ explained $71 \%$ of total variation in the data set. The variables most associated with component 1 , in descending order of factorial loading, were residual-P (0.90), sonic-Po (0.88), $\mathrm{NaHCO}_{3}-\mathrm{Po}(0.86), \mathrm{NaOH}-\mathrm{Po}(0.81)$ and sonic-Pi (0.74). The fractions of resin-Pi and $\mathrm{NaHCO}_{3}$-Pi were closely associated to component 2, with factorial loading of 0.94 and 0.92 , respectively. They contributed little to dissimilarity between sites, such as fractions of $\mathrm{NaOH}-\mathrm{Pi}$ and $\mathrm{HCl}-\mathrm{Pi}$, which had weak association $(<0.70)$ with the two first components (Figure 1).

There was wide variation in content for all $\mathrm{P}$ fractions across the sites (Table 3 ), as well as in the relative contribution of $\mathrm{P}$ fractions to total extracted $\mathrm{P}$ (Figure 2). The labile $\mathrm{P}$ (resin-Pi $+\mathrm{Pi}$ and Po in $\mathrm{NaHCO}_{3}$ ) varied between $6 \%$ and $16 \%$ (average of $10 \%$ ), the moderately labile $\mathrm{P}(\mathrm{Pi}+\mathrm{Po}$ in $\mathrm{NaOH}$ ), varied between $28 \%$ and $40 \%$ (average of $35 \%$ ), the occluded $\mathrm{P}(\mathrm{Pi}+\mathrm{Po}$ in Sonicate $+\mathrm{NaOH})$ varied between $6 \%$ and $19 \%$ (average of $12 \%$ ), the $\mathrm{P}$ associated to $\mathrm{Ca}(\mathrm{HCl}-\mathrm{Pi})$ varied between $0.4 \%$ and $3 \%$ (average of $1.4 \%$ ) and the residual-P varied between $35 \%$ and $47 \%$ (average of $42 \%$ ). The Po corresponded in average to $70 \%$ of total labile $\mathrm{P}, 51 \%$ of moderately labile $\mathrm{P}$ and $53 \%$ of occluded $\mathrm{P}$ (Table 3). Although the soil samples present variations across the organic and inorganic fractions, in general the relative proportions of total $\mathrm{Pi}$ and $\mathrm{Po}$, in relation to total extracted $\mathrm{P}$, were similar. Values varied between $18 \%$ and $37 \%$ for total $\mathrm{Pi}$ (average of $28 \%$ ) and between $16 \%$ and $37 \%$ for total Po (average of 30\%) (Figure 3). Thus, the geochemical P (total Pi + residual-P) constituted around $70 \%$ of total extracted $P$. 


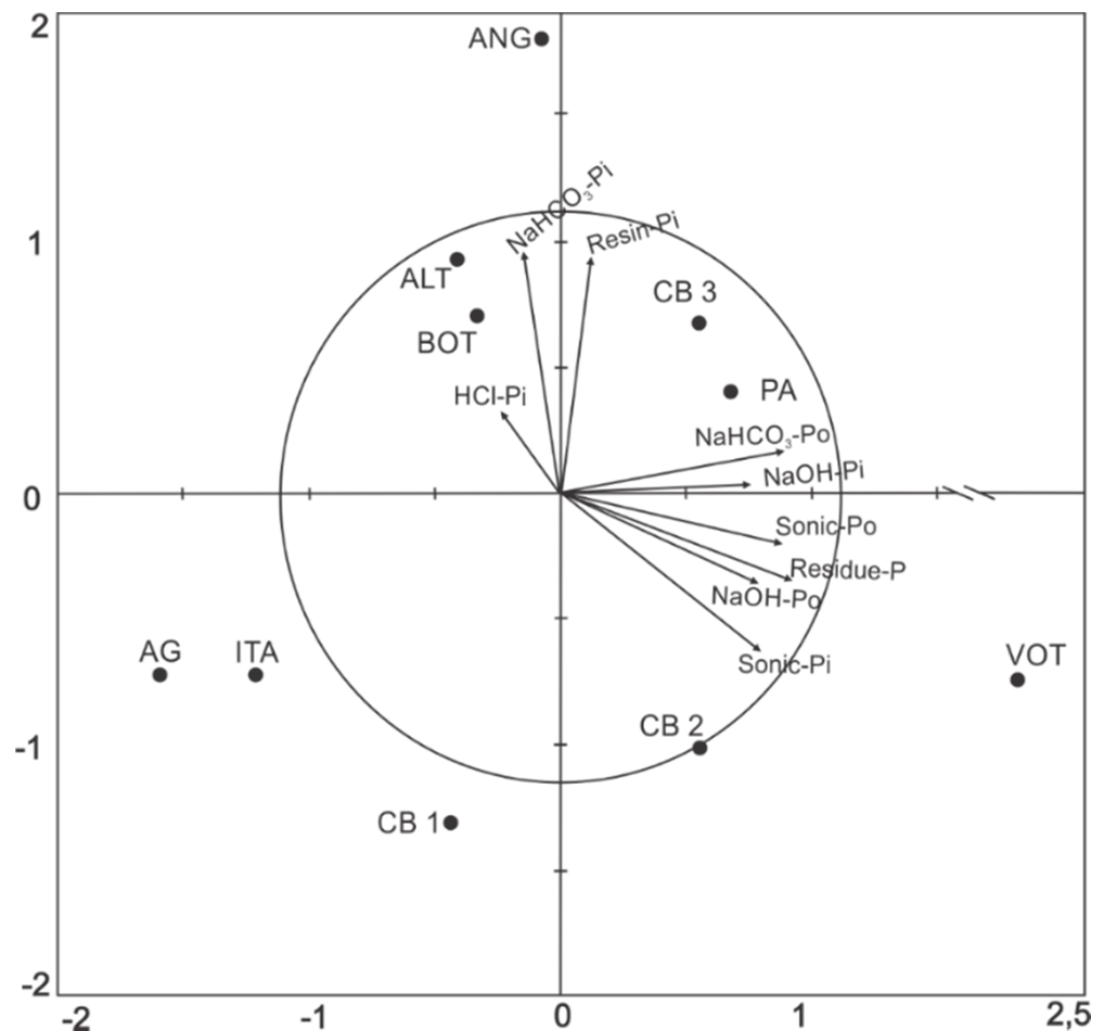

Figure 1. Ordination diagram produced by principal component analysis of soil $\mathrm{P}$ fractions $(0-20 \mathrm{~cm})$ in Brazilian Eucalyptus plantations. Sites: AG-Agudos, ANG-Angatuba, BOT_Botucatu, ITA-Itatinga, ALT-Altinópolis, CB1-Capão Bonito 1, CB2—Capão Bonito 2, CB3-Capão Bonito 3, PA—Paraibuna, VOT-Votorantim.

Table 3. P fractions of soils $(0-20 \mathrm{~cm})$ under Brazilian Eucalyptus plantations.

\begin{tabular}{|c|c|c|c|c|c|c|c|c|c|}
\hline Site * & $\begin{array}{c}\text { Resin } \\
\text { Pi }\end{array}$ & $\underset{\mathrm{Pi}}{\mathrm{NaHCO}_{3}}$ & $\underset{\text { Po }}{\mathrm{NaHCO}_{3}}$ & $\underset{\mathrm{Pi}}{\mathrm{NaOH}}$ & $\begin{array}{c}\mathrm{NaOH} \\
\mathrm{Po}\end{array}$ & $\begin{array}{c}\text { Sonic } \\
\text { Pi }\end{array}$ & $\begin{array}{l}\text { Sonic } \\
\text { Po }\end{array}$ & $\begin{array}{c}\mathrm{HCl} \\
\mathrm{Pi}\end{array}$ & $\begin{array}{c}\text { Residue } \\
\mathbf{P}\end{array}$ \\
\hline & \multicolumn{9}{|c|}{$-\mathbf{m g} \cdot \mathbf{k g}^{-1}$} \\
\hline AG & $3.4 \mathrm{C}$ & $4.4 \mathrm{C}$ & $19.1 \mathrm{~B}$ & $45.0 \mathrm{~B}$ & $33.8 \mathrm{E}$ & $7.7 \mathrm{~B}$ & $5.6 \mathrm{D}$ & $3.4 \mathrm{C}$ & $81.9 \mathrm{~F}$ \\
\hline ANG & $8.5 \mathrm{~A}$ & $12.9 \mathrm{~A}$ & $23.6 \mathrm{~B}$ & 53.5 B & $59.1 \mathrm{D}$ & $7.3 \mathrm{~B}$ & $16.0 \mathrm{C}$ & $3.1 \mathrm{C}$ & $98.3 \mathrm{~F}$ \\
\hline BOT & $6.9 \mathrm{~A}$ & $7.0 \mathrm{~B}$ & $26.7 \mathrm{~B}$ & $52.2 \mathrm{~B}$ & $59.2 \mathrm{D}$ & $7.9 \mathrm{~B}$ & $17.6 \mathrm{C}$ & $3.6 \mathrm{C}$ & $108.7 \mathrm{~F}$ \\
\hline ITA & $2.5 \mathrm{C}$ & $6.4 \mathrm{~B}$ & $17.9 \mathrm{~B}$ & 47,2 B & $62.0 \mathrm{D}$ & $12.3 \mathrm{~B}$ & $13.3 \mathrm{C}$ & $6.2 \mathrm{~B}$ & $142.3 \mathrm{E}$ \\
\hline ALT & $5.2 \mathrm{~B}$ & $8.2 \mathrm{~B}$ & $22.6 \mathrm{~B}$ & $83.1 \mathrm{~A}$ & $19.9 \mathrm{~F}$ & $10.9 \mathrm{~B}$ & $8.5 \mathrm{D}$ & $10.5 \mathrm{~A}$ & $150.9 \mathrm{E}$ \\
\hline CB1 & $2.8 \mathrm{C}$ & $2.8 \mathrm{C}$ & $21.0 \mathrm{~B}$ & $73.2 \mathrm{~A}$ & $78.5 \mathrm{C}$ & $43.3 \mathrm{~A}$ & $18.0 \mathrm{C}$ & $3.7 \mathrm{C}$ & $169.9 \mathrm{D}$ \\
\hline CB2 & $4.3 \mathrm{~B}$ & $2.1 \mathrm{C}$ & $25.8 \mathrm{~B}$ & $76.1 \mathrm{~A}$ & $98.0 \mathrm{~B}$ & $52.0 \mathrm{~A}$ & $46.5 \mathrm{~B}$ & $3.2 \mathrm{C}$ & 214.6 B \\
\hline CB3 & $5.0 \mathrm{~B}$ & $7.2 \mathrm{~B}$ & $35.0 \mathrm{~A}$ & $79.3 \mathrm{~A}$ & $79.3 \mathrm{C}$ & $18.1 \mathrm{~B}$ & $17.0 \mathrm{C}$ & $6.6 \mathrm{~B}$ & $165.9 \mathrm{D}$ \\
\hline PA & $5.2 \mathrm{~B}$ & $7.4 \mathrm{~B}$ & $25.8 \mathrm{~B}$ & $84.5 \mathrm{~A}$ & $38.3 \mathrm{E}$ & $26.3 \mathrm{~B}$ & $58.4 \mathrm{~A}$ & $4.0 \mathrm{C}$ & $188.6 \mathrm{C}$ \\
\hline VOT & $3.5 \mathrm{C}$ & $4.4 \mathrm{C}$ & $38.2 \mathrm{~A}$ & $73.9 \mathrm{~A}$ & $166.8 \mathrm{~A}$ & $49.6 \mathrm{~A}$ & $67.7 \mathrm{~A}$ & $2.6 \mathrm{C}$ & $332.3 \mathrm{~A}$ \\
\hline Mean & 4.7 & 6.3 & 25.6 & 66.8 & 69.5 & 23.5 & 26.9 & 4.7 & 165.3 \\
\hline
\end{tabular}

Groups of means with different letters in the columns differ between itself by Scott \& Knott test at $5 \%$ probability. AG-Agudos, ANG-Angatuba, BOT—Botucatu, ITA-Itatinga, ALT—Altinópolis, CB1—Capão Bonito 1, CB2-Capão Bonito 2, CB3 - Capão Bonito 3, PA-Paraibuna, VOT-Votorantim. 




Figure 2. Relative distribution of total organic $\mathrm{P}$, total inorganic $\mathrm{P}$ and residue $\mathrm{P}$ fractions of total $\mathrm{P}$ in soils under Brazilian Eucalyptus plantations. Sites: AG-Agudos, ANG-Angatuba, BOT-Botucatu, ITA-Itatinga, ALT-Altinópolis, CB1-Capão Bonito 1, CB2-Capão Bonito 2, CB3-Capão Bonito 3, PA-Paraibuna, VOT_-Votorantim.



Figure 3. Soil $\mathrm{P}$ fractions for each Eucalyptus site as a percentage of total P. Sites: AG-Agudos, ANG-Angatuba, BOT-Botucatu, ITA-Itatinga, ALT-Altinópolis, CB1-Capão Bonito 1, CB2-Capão Bonito 2, CB3-Capão Bonito 3, PA—Paraibuna, VOT-Votorantim. Labile P (Resin-Pi + Pi and $\mathrm{Po}$ in $\mathrm{NaHCO}_{3}$ ), moderately labile $\mathrm{P}$ ( $\mathrm{Pi}$ and $\mathrm{Po}$ in $\mathrm{NaOH}$ ), occluded $\mathrm{P}$ ( $\mathrm{Pi}$ and $\mathrm{Po}$ in Sonicate $+\mathrm{NaOH}), \mathrm{Ca}-\mathrm{P}(\mathrm{HCl}-\mathrm{Pi})$ and residue-P.

\subsection{Relations between P Fractions and Soil Attributes}

Significant correlations were observed across all $\mathrm{P}$ fractions, except for $\mathrm{NaOH}-\mathrm{Pi}$ and $\mathrm{HCl}-\mathrm{Pi}$ (Table 4), which corroborates the results of PCA (Figure 1). The resin-Pi demonstrated a positive relationship with only $\mathrm{NaHCO}_{3}-\mathrm{Pi}$, which correlated negatively to sonic-Pi. All organic fractions and the sonic-Pi showed positive correlation with residual-P. Regarding soil attributes, there were negative correlations between $\mathrm{NaHCO}_{3}$-Pi and clay content and cation exchange capacity (CEC at pH 7.0). The fractions of $\mathrm{NaOH}-\mathrm{Po}$, sonic-Pi and residual-P demonstrated a positive correlation with the contents of 
clay and organic $C$ and with CEC, and Sonic-Po fraction with both clay and organic C. No significant correlations between the other $P$ fractions and soil attributes were found (Table 5).

Table 4. Pearson correlation coefficients for soil P fractions $(0-20 \mathrm{~cm})$ in Brazilian Eucalyptus plantations.

\begin{tabular}{|c|c|c|c|c|c|c|c|c|c|}
\hline Fractions & $\begin{array}{c}\text { Resin } \\
\text { Pi }\end{array}$ & $\begin{array}{c}\mathrm{NaHCO}_{3} \\
\mathbf{P i}\end{array}$ & $\begin{array}{c}\mathrm{NaHCO}_{3} \\
\mathrm{Po}\end{array}$ & $\begin{array}{c}\mathrm{NaOH} \\
\mathrm{Pi}\end{array}$ & $\begin{array}{c}\mathrm{NaOH} \\
\text { Po }\end{array}$ & $\begin{array}{c}\text { Sonic } \\
\text { Pi }\end{array}$ & $\begin{array}{c}\text { Sonic } \\
\text { Po }\end{array}$ & $\begin{array}{c}\mathrm{HCl} \\
\mathbf{P i}\end{array}$ & $\begin{array}{c}\text { Residue } \\
\text { P }\end{array}$ \\
\hline Resin $\mathrm{Pi}$ & 1 & $0.78 * *$ & 0.13 & -0.05 & -0.27 & -0.45 & -0.11 & -0.05 & -0.37 \\
\hline $\mathrm{NaHCO}_{3} \mathrm{Pi}$ & - & 1 & -0.04 & -0.16 & -0.40 & -0.69 * & -0.28 & 0.23 & -0.43 \\
\hline $\mathrm{NaHCO}_{3} \mathrm{Po}$ & - & - & 1 & 0.48 & $0.71 *$ & 0.41 & 0.60 & -0.17 & 0.70 * \\
\hline $\mathrm{NaOH} \mathrm{Pi}$ & - & - & - & 1 & 0.17 & 0.54 & 0.50 & 0.31 & 0.58 \\
\hline $\mathrm{NaOH} \mathrm{Po}$ & - & - & - & - & 1 & $0.74 *$ & $0.65 *$ & -0.49 & $0.83^{* *}$ \\
\hline Sonic Pi & - & - & - & - & - & 1 & 0.73 * & -0.39 & $0.82 * *$ \\
\hline Sonic Po & - & - & - & - & - & - & 1 & -0.45 & $0.85^{* *}$ \\
\hline $\mathrm{HCl} \mathrm{Pi}$ & - & - & - & - & - & - & - & 1 & -0.18 \\
\hline Residue P & - & - & - & - & - & - & - & - & 1 \\
\hline
\end{tabular}

Significant at ${ }^{* *} p<0.01 ;{ }^{*} p<0.05$.

Table 5. Pearson correlation coefficients between $P$ fractions and soil attributes $(0-20 \mathrm{~cm})$ in Brazilian Eucalyptus plantations.

\begin{tabular}{ccccccc}
\hline Fractions & Clay & $\mathbf{C}$ & $\mathbf{p H}$ & $\mathrm{SB}$ & Al sat. & CEC \\
\hline Resin $\mathrm{Pi}$ & -0.47 & -0.43 & 0.42 & 0.04 & -0.58 & -0.56 \\
$\mathrm{NaHCO}_{3} \mathrm{Pi}$ & $-0.69^{*}$ & -0.55 & -0.03 & -0.27 & -0.34 & $-0.68^{*}$ \\
$\mathrm{NaHCO}_{3} \mathrm{Po}$ & 0.47 & 0.59 & 0.41 & 0.41 & -0.15 & 0.61 \\
$\mathrm{NaOH} \mathrm{Pi}$ & 0.46 & 0.37 & 0.59 & 0.52 & -0.37 & 0.41 \\
$\mathrm{NaOH} \mathrm{Po}$ & $0.79^{* *}$ & $0.88^{* * *}$ & 0.04 & 0.15 & 0.37 & $0.82^{* *}$ \\
$\mathrm{Sonic} \mathrm{Pi}$ & $0.98^{* * *}$ & $0.86^{* *}$ & 0.28 & 0.35 & 0.23 & $0.82^{* *}$ \\
$\mathrm{Sonic} \mathrm{Po}$ & $0.78^{* *}$ & $0.73^{*}$ & 0.27 & 0.29 & -0.08 & 0.51 \\
$\mathrm{HCl} \mathrm{Pi}$ & -0.48 & -0.37 & -0.06 & 0.12 & -0.37 & -0.24 \\
Residue P & $0.84^{* *}$ & $0.91^{* * *}$ & 0.18 & 0.29 & 0.10 & $0.78^{* *}$ \\
\hline \\
\hline ge capacity.
\end{tabular}

\subsection{Soil P Transformations}

The hypothetical structural model of soil $\mathrm{P}$ cycle was composed of four $\mathrm{P}$ pools (latent variables): (i) the organic fractions in $\mathrm{NaHCO}_{3}$ and $\mathrm{NaOH}$ were grouped in the organic pool; (ii) the recalcitrant fraction residual-P and sonic-P (Pi and Po), in the occluded pool; (iii) the $\mathrm{NaHCO}_{3}$-Pi fraction, in the inorganic pool, and (iv) the resin-Pi only in the available pool (Figure 4). The general fitting of the model was highly satisfactory $\left(X^{2}=14.03, d f=9, P=0.121\right.$; GFI $=0.891 ; C F I=0.957$; RMSEA $\left.=0.139\right)$. The available $\mathrm{P}$ pool (endogenous latent variable) was directly dependent on pools of inorganic $\mathrm{P}(\mathrm{Pi})$, organic $\mathrm{P}(\mathrm{Po})$ (endogenous latent variables) and occluded $\mathrm{P}$ (exogenous latent variable). However, only the Pi pool had significant direct effects on the available P pool. In turn, the exclusion of direct relationships between the pools of Po and occluded P with the available P pool decreases the model's fit, thereby justifying the relevance of these two pools in the model. Thus, these three pools together explained $50 \%$ of total variance in the available $\mathrm{P}$ pool. The Po pool had also an indirect negative effect via Pi pool on the available P pool, causing a general negative effect $(\beta=-0.27+\{(-0.22) \times 0.66\}=$ $-0.415)$. The occluded $\mathrm{P}$ pool had an indirect negative effect on the pools of $\mathrm{Po}+\mathrm{Pi}$ and positive effect via Pi pool, but its general effect was positive $(\beta=0.30+\{(0.90 \times(-0.27))+(0.63 \times 0.66)+(0.90 \times$ $(-0.22) \times 0.66)\}=0.342)$. Therefore, the overall effect of these three pools on the available P pool was positive $(\beta=(-0,415)+0.342+0.66=0.587)$. 


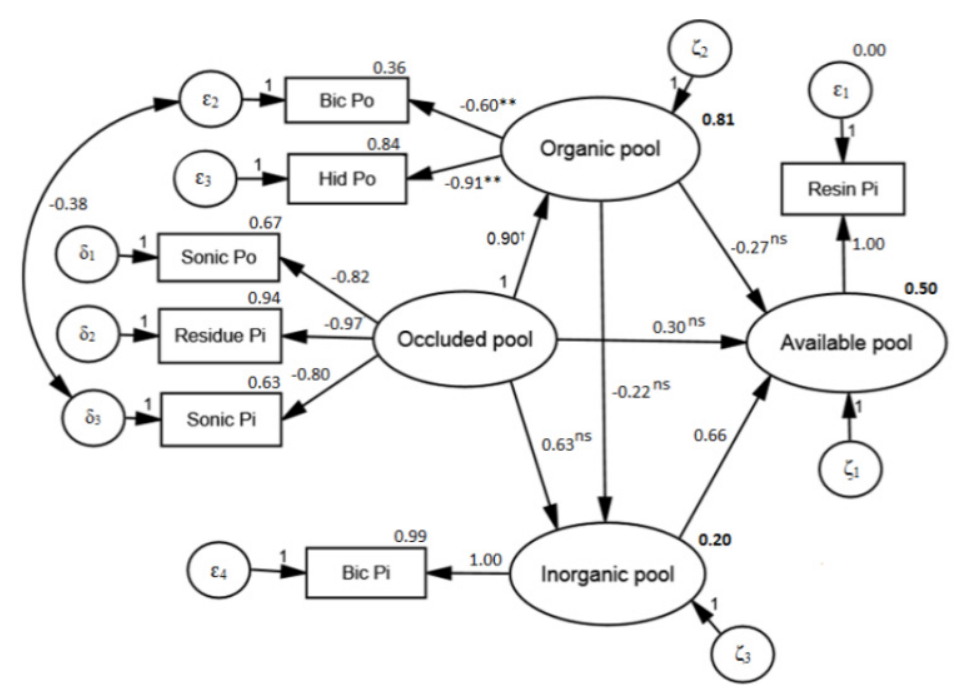

Figure 4. Structural equation modeling for the soil P cycle in Brazilian plantations. All measured variables (in boxes) are represented as effect indicators associated with latent variables (in circles). The numbers correspond to the standardized parameters estimated $(p<0.001)$ and the $R$-squared values (numbers in bold). ${ }^{\dagger}$ Significant at $p<0.10,{ }^{*}$ at $p<0.05,{ }^{* *}$ at $p<0.01$. Error variables $\left(\varepsilon_{1}-\varepsilon_{5}, \delta_{1}-\delta_{3}\right)$ are standardized values. Model $X^{2}=14.03, d f=9, p=0.121$.

\section{Discussion}

\subsection{Distribution of Organic and Inorganic P Fractions}

The high level of dissimilarity among P fractions suggests that each Eucalyptus site consisted of a specific environment and any change in production system, management practices and soil conditions could therefore affect the dynamics of $\mathrm{P}$. The sites presenting the greatest clay content also showed the greatest organic $\mathrm{C}$ content and $\mathrm{CEC}$ (at $\mathrm{pH} 7$ ) (Table 2). Variables highly correlated with each other $(r=0.87, p<0.001$ between clay and C; $r=0.85, p<0.01$ between clay and CEC; $r=0.87, p<0.01$ between $C$ and $C E C$ ). In these sites, the greatest contents of total Po were found, evidencing the strong correlation between Po and soil organic matter [6,9]. Thus, forest management practices that increase soil organic matter tend to lead to an increase of $P$ stocks in organic forms.

An average content of $6.6 \mathrm{mg} \cdot \mathrm{kg}^{-1}$ of resin-Pi is common in tropical soils of low natural fertility and unfertilized soils $[18,21,30,31]$. The predominance of $\mathrm{Po}_{\mathrm{o}} \mathrm{NaHCO}_{3}$ and $\mathrm{NaOH}$ fractions, in most of the sites, had significant linkages to the availability of $\mathrm{P}$ to plants. In tropical soils of low fertility, the organic forms of $\mathrm{P}$ are considered the main sources of $\mathrm{P}$ to plants [32-34], if the maintenance of Po stocks occurs through the process of organic matter recycling.

The organic fractions remained similar to the inorganic fractions, with approximately $30 \%$ of total $\mathrm{P}$ in each (excluding the residual-P). This proportion of Po is within the range found in tropical regions for several soil orders (from low to medium content of organic $C$ ) and land-use systems, with average values of total Po from $26 \%[9,35,36]$ to $31 \%$ [11,19,37]. Oliveira et al. [38] found proportions of total Po ranging from $36 \%$ to $46 \%$ for soils with high contents of organic matter, a conclusion that supports these findings. The results of the current study suggest that the minimum cultivation system could be a management strategy in the maintenance of high soil Po contents in Eucalyptus plantations in Brazil. Residue retention on the soil surface increased organic matter and nutrient status in Eucalyptus sites [4].

The content of fractions that compose labile $\mathrm{P}$ (resin-Pi $+\mathrm{Pi}$ and $\mathrm{Po}$ in $\mathrm{NaHCO}_{3}$ ) are within the range found by other authors in several soil orders and land-use systems [14,35,39]. The average content of $37 \mathrm{mg} \cdot \mathrm{kg}^{-1}$ of labile $\mathrm{P}$, which corresponds to an average quantity of $73 \mathrm{~kg} \cdot \mathrm{ha}^{-1}$ of labile $\mathrm{P}$ (bulk density $=1 \mathrm{~g} \cdot \mathrm{dm}^{-3}$ ), could satisfy demand for immobilized $\mathrm{P}$ in the aboveground biomass of Eucalyptus (leaves, branches, wood and bark), in a cultivation cycle of seven years, assuming 
the predominance of the P mineralization process of immobilization. Eucalyptus production with a cultivation cycle of 7 years accumulates between 23 and $38 \mathrm{~kg} \cdot \mathrm{ha}^{-1}$ of $\mathrm{P}$ [40-43]. Thus, in all sites there is potential supply for a high demand of $\mathrm{P}\left(50 \mathrm{~kg} \cdot \mathrm{ha}^{-1}\right)$ in Eucalyptus plantations [44,45]. This indicates the need to improve routine analysis methods for the quantification of available $P$ in soil.

The maintenance of forest residues, such as bark and canopy, has a great effect on P availability in forest sites; together they represent between $57 \%$ and $70 \%$ of $\mathrm{P}$ accumulated in the aboveground biomass of Eucalyptus $[3,42,43,46]$. These sources partially replace the element quantity in the labile fraction, decreasing demand for phosphorus fertilization.

The contents of moderately labile $\mathrm{P}$ and occluded $\mathrm{P}$ were higher than the average values reported by Gama-Rodrigues et al. [21] for different tropical soil orders. The HCl-Pi contents were within the range expected for highly weathered tropical soils [14], which were found in relative proportions of less than $1 \%$. The residual-P contents were also within the expected range for most tropical soils $[14,21,31,39]$, although in reality this $P$ fraction is only used in the long term by the Eucalyptus, as it is not affected in the short term by soil management systems and fertilizer application [47].

\subsection{Structural Model}

In spite of demonstrating association between most $\mathrm{P}$ fractions, the simple correlation analysis did not provide enough information to distinguish the direct and indirect effects of all $\mathrm{P}$ fractions on resin-Pi. Thus, by applying the SEM method, it was possible to quantify levels of interdependence among $\mathrm{P}$ pools and consequently the cause-effect relationship in the transformation of $\mathrm{P}$ in soil could be established.

The structural model of $\mathrm{P}$ transformations in soil showed that pools of Pi and occluded P act as sources and Po pools act as a sink of $\mathrm{P}$ for the available $\mathrm{P}$ pool. The main source of $\mathrm{P}$ was the $\mathrm{Pi}$ pool $(\beta=0.66)$ once the source function of the occluded $P$ pool $(\beta=0.342)$ was counterbalanced by the sink function of the Po pool $(\beta=-0.415)$. The adjusted model demonstrated the complexity of the inter-relation of geochemical and biological processes on the available $\mathrm{P}$ pool, validating the theoretical concept that indicators of $\mathrm{P}$ pools are fractions of $\mathrm{P}$ determined by the sequential extraction method, as reported by Sales et al. [34]. In addition, the HCl-Pi fraction, as an indicator of the primary mineral $\mathrm{P}$ pool, was not part of the adjusted model likely because all soil orders used for modeling are strongly weathered (Table 1). This fraction represented on average only $1.4 \%$ of the total P extracted (Figure 3).

The direct and indirect effects (via Pi pool) of the occluded pool as a source of P on the available P pool can be attributed to the dissolution of stable forms of Pi and/or to the mineralization of stable forms of Po found in residual-P fraction, besides the Sonic-Po fraction itself, as indicator variables of this pool. The presence of stable forms of Po in the occluded pool would partially explain its positive relationship with the Po pool [34].

However, the transformations of recalcitrant forms of Po from the occluded pool to labile and moderately labile forms of the Po pool did not result in indirect positive effects of occluded pool on the available P pool. These results suggest that in the Po pool there is a deficit of several forms of Po, which are characteristic of cultivation conditions with no or low phosphorus fertilizer supply in several Eucalyptus sites that have soils lacking in P (Table 1).

This deficit reveals the sink function of the Po pool, evidencing the predominance of the immobilization process in relation to mineralization, once the enrichment of available $\mathrm{P}$ and Pi pools has caused a reduction of $\mathrm{P}$ in the organic pool. Under these conditions, the input of Pi and Po in soil solution via mineralization/decomposition of plant litter/roots can increase the Po pool. Pi can be immobilized by several species of organic anions through complexion reactions and chelation [48,49]. Several forms of labile and moderately labile Po can be adsorbed on soil minerals in varying levels of stability [50], thus decreasing the concentration of these organic compounds in soil solution and, consequently, their availability for mineralization.

The adjusted model therefore shows that $\mathrm{P}$ bioavailability is regulated by the interaction between pools of Po, Pi and occluded P (Figure 4). The lability of P progresses over time for all fractions in 
such a way that, in the long term, all soil $\mathrm{P}$ can become labile [17]. Thus in soils poor in P, plants can acquire $\mathrm{P}$ in more recalcitrant forms through several acquisition strategies-for instance, through root exudation of organic anions and phosphatases that increases the desorption, solubilization or mineralization of $P$ from sparingly-availability sources in soil [51]. The organic anions can also reduce the soil's capacity for P-fixation as they occupy adsorption sites on mineral phase [52]. Additionally, the extension of root systems and association with mycorrhizal fungi are other strategies to improve $\mathrm{P}$ acquisition [53,54].

In this context, Eucalyptus trees, which require relatively long cultivation cycles and present high fine roots and root hairs production [4], elevated root activity of acid phosphatase [55] and intense mycorrhizal associations [56], have access to all $\mathrm{P}$ pools to satisfy their demand for P. All these strategies for nutrient acquisition can increase the capacity of plants of acquiring soil $\mathrm{P}$ and accelerating the recycling rate, although not the quantity, of $P$ within the ecosystems [57]. Nevertheless, in the evaluated Eucalyptus sites, the reversion of Po pool from sink function to source on the available pool P was not warranted (Figure 4) creating a need to enhance management practices to ensure this outcome. Mixed-species plantations of Eucalyptus with nitrogen-fixing trees have the potential to increase both levels of soil labile Po and soil phosphatase activity [58]. Therefore, hypothetically, leguminous trees can increase the quality of soil organic matter, which could lead to reversion of the sink function of the Po pool (Figure 4), thus increasing P bioavailability for Eucalyptus trees. To verify this model, the improvement of regression coefficient adjustments to structural relations is still required, as well as verification using independent data from Eucalyptus sites. This is because the sink function of Po pool on the available P pool differed from the structural models proposed by Gama-Rodrigues et al. [21] and Sales et al. [34], in which the Po pool acted as a source of $P$ in unfertilized tropical soils in different land uses. Additionally, 50\% of unexplained variance in available P pool in our model suggesting that there are additional unmeasured factors that could also influence $P$ availability (Figure 4). Thus, the SEM method cannot be used to rule out the possibility that other untested models could provide an even better fit [59].

\section{Conclusions}

1. There is great dissimilarity across forestry sites regarding $P$ fractions in soil, caused by differences in the physical and chemical attributes of soil and in forest management practices.

2. The fractionation procedure of P establishes the potential for labile fractions to supply Eucalyptus trees, which is not possible in routine methods for analysis of soil fertility.

3. The structural model is adequate to identify functional pools of $\mathrm{P}$ in soil and to identify transformation processes of $\mathrm{P}$ in soil, based on the source-sink relationships.

4. The available P pool is highly dependent on inorganic and occluded pool and the organic pool acts predominantly as a sink of $\mathrm{P}$ on available and inorganic pools. This demonstrates the high level of recalcitrance of the organic pool and the fact that Eucalyptus plants must access pools of limited-availability $\mathrm{P}$ in order to meet their nutritional demands.

Acknowledgments: We thank the Rio de Janeiro Research Foundation (FAPERJ) for the award of a research fellowship to Antonio Carlos Gama-Rodrigues. We also thank the Brazilian National Council for Scientific and Technological Development (CNPq)-grant 2013/475222-0 (Universal Project), and São Paulo Research Foundation (FAPESP)—grant 2010/16623-9 (Thematic Project) for their financial support. We would also like to thank the Escola Superior de Agricultura Luiz de Queiroz (ESALQ/USP) and Instituto de Pesquisas e Estudos Florestais (IPEF) for their technical support. We also thank Estela Covre Foltran for her helpful comments.

Author Contributions: Antonio Carlos Gama-Rodrigues and José Leonardo de Moraes Gonçalves designed the study and conducted the field trial. José Leonardo de Moraes Gonçalves was responsible for the soil sample collection. Marlon Gomes Costa was responsible for laboratory analysis. Marlon Gomes Costa, Marcus Vinicius da Silva Sales and Seldon Aleixo were responsible for statistical analyses, with contributions from Antonio Carlos Gama-Rodrigues. Marlon Gomes Costa, Antonio Carlos Gama-Rodrigues, José Leonardo de Moraes Gonçalves and Emanuela Forestieri Gama-Rodrigues wrote the paper.

Conflicts of Interest: The authors declare no conflict of interest. 


\section{References}

1. Booth, T.H. Eucalypt plantations and climate change. For. Ecol. Manag. 2013, 301, 28-34. [CrossRef]

2. Laclau, J.P.; Goncalves, J.L.D.; Stape, J.L. Perspectives for the management of eucalypt plantations under biotic and abiotic stresses. For. Ecol. Manag. 2013, 301, 1-5. [CrossRef]

3. Bazani, J.H.; Gonçalves, J.L.M.; Rocha, J.H.T.; Melo, E.S.A.C.; Prieto, M. Nutrição fosfatada em plantações de eucalipto. Info. Agron. 2014, 148, 1-11.

4. Gonçalves, J.L.M.; Alvares, C.A.; Higa, A.R.; Silva, L.D.; Alfenas, A.C.; Stahl, J.; Ferraz, S.F.B.; Lima, W.P.; Brancalion, P.H.S.; Hubner, A.; et al. Integrating genetic and silvicultural strategies to minimize abiotic and biotic constraints in Brazilian eucalypt plantations. For. Ecol. Manag. 2013, 301, 6-27. [CrossRef]

5. Gonçalves, J.L.M. Fertilização de Plantação de Eucalipto. In Encontro brasileiro de Silvicultura, 2011; Gonçalves, J.L.M., Pulito, A.P., Arthur Junior, J.C., Silva, L.D., Eds.; Anais Piracicaba: Piracicaba, Brazil, 2011; pp. 85-114.

6. Turner, B.L.; Engelbrecht, B.M.J. Soil organic phosphorus in lowland tropical rain forests. Biogeochemistry. 2011, 103, 297-315. [CrossRef]

7. Yang, X.; Post, W.M. Phosphorus transformation as a function of pedogenesis: A synthesis of soil phosphorus data using Hedley fractionation method. Biogeosciences 2011, 8, 2907-2916. [CrossRef]

8. Condron, L.M.; Turner, B.L.; Cade-Menun, B.J. Chemistry and dynamics of soil organic phosphorus. In Phosphorus: Agriculture and the Environment, Agronomy Monograph 46; Sims, J.T., Sharpley, A.N., Eds.; SSSA: Madison, WI, USA, 2005; pp. 87-121.

9. Cunha, G.M.; Gama-Rodrigues, A.C.; Costa, G.S.; Velloso, A.C.X. Fósforo orgânico em solos sob florestas montanas, pastagens e eucalipto no Norte Fluminense. Rev. Bras. Ciênc. Solo 2007, 31, 667-672. [CrossRef]

10. Turner, B.L. Resource partitioning for soil phosphorus: A hypothesis. J. Ecol. 2008, 96, 698-702. [CrossRef]

11. Zaia, F.C.; Gama-Rodrigues, A.C.; Gama-Rodrigues, E.F. Formas de fósforo no solo sob leguminosas florestais, floresta secundária e pastagem no Norte Fluminense. Rev. Bras. Ciênc. Solo 2008, 32, 1191-1197. [CrossRef]

12. Hedley, M.J.; Stewart, J.W.B.; Chauhan, B.S. Changes in inorganic and organic soil-phosphorus fractions induced by cultivation practices and by laboratory incubations. Soil Sci. Soc. Am. J. 1982, 46, 970-976. [CrossRef]

13. Condron, L.M.; Newman, S. Revisiting the fundamentals of phosphorus fractionation of sediments and soils. J. Soils Sediment. 2011, 11, 830-840. [CrossRef]

14. Cross, A.F.; Schlesinger, W.H. A literature review and evaluation of the Hedley fractionation: Applications to the biogeochemical cycle of soil phosphorus in natural ecosystems. Geoderma 1995, 64, 197-214. [CrossRef]

15. Negassa, W.; Leinweber, P. How does the Hedley sequential phosphorus fractionation reflect impacts of land use and management on soil phosphorus: A review. J. Plant Nutr. Soil Sci. 2009, 172, 305-325. [CrossRef]

16. Tiessen, H.; Stewart, J.W.B.; Cole, C.V. Pathways of phosphorus transformations in soils of differing pedogenesis. Soil Sci. Soc. Am. J. 1984, 48, 853-858. [CrossRef]

17. Guo, F.; Yost, R.S. Partitioning soil phosphorus into three discrete pools of differing availability. Soil Sci. 1998, 163, 822-832. [CrossRef]

18. Cardoso, I.; Janssen, B.; Oenema, O.; Kuyper, T. Phosphorus pools in Oxisols under shaded and unshaded coffee systems on farmers' fields in Brazil. Agrofor. Syst. 2003, 58, 55-64. [CrossRef]

19. Frizano, J.; Vann, D.R.; Johnson, A.H.; Johnson, C.M.; Vieira, I.C.G.; Zarin, D.J. Labile phosphorus in soils of forest fallows and primary forest in the Bragantina region, Brazil. Biotropica 2003, 35, 2-11. [CrossRef]

20. Gatiboni, L.C.; Brunetto, G.; Rheinheimer, D.S.; Kaminsk, J. Fracionamento químico das formas de fósforo do solo: Uso e limitações. Tóp. Ciênc. Solo 2013, 8, 141-187.

21. Gama-Rodrigues, A.C.; Sales, M.V.S.; Silva, P.S.D.; Comerford, N.B.; Cropper, W.P.; Gama-Rodrigues, E.F. An exploratory analysis of phosphorus transformations in tropical soils using structural equation modeling. Biogeochemistry 2014, 118, 453-469. [CrossRef]

22. Barros, N.F.; Novais, R.F. Eucalipto. In Recomendações para uso de Corretivos e Fertilizantes em Minas Gerais, 5th ed.; Ribeiro, A.C., Guimarães, P.T.G., Alvarez, V.V.H., Eds.; UFV: Viçosa, Brazil, 1999; pp. 303-305.

23. Empresa Brasileira de Pesquisa Agropecuária-Embrapa. Manual de Análises Químicas de Solos, Plantas e Fertilizantes; Empresa Brasileira de Pesquisa Agropecuária: Brasília, Brazil, 1999.

24. Alvarez, V.V.H.; Ribeiro, A.C. Calagem. In Recomendação Para Uso de Corretivos e Fertilizantes em Minas Gerais, 5th ed.; Ribeiro, A.C., Guimarães, P.T.G., Alvarez, V.V.H., Eds.; UFV: Viçosa, Brazil, 1999; pp. 43-60. 
25. Murphy, J.; Riley, J.P. A modified single solution method for the determination of phosphate in natural waters. Anal. Chim. Acta. 1962, 27, 31-36. [CrossRef]

26. Dick, W.A.; Tabatabai, M.A. Determination of orthophosphate in aqueous solutions containing labile organic and inorganic phosphorus compounds. J. Environ. Qual. 1977, 6, 82-85. [CrossRef]

27. Zaia, F.C.; Gama-Rodrigues, A.C.; Gama-Rodrigues, E.F.; Moço, M.K.S.; Fontes, A.G.; Machado, R.C.R.; Baligar, V.C. Carbon, nitrogen, organic phosphorus, microbial biomass and $\mathrm{N}$ mineralization in soils under cacao agroforestry systems in Bahia, Brazil. Agrofor. Syst. 2012, 86, 197-212. [CrossRef]

28. Lima, A.M.N.; Silva, I.R.; Neves, J.C.L.; Novais, R.F.; Barros, N.F.; Mendonça, E.S.; Smyth, T.J.; Moreira, M.S.; Leite, F.P. Soil organic carbon dynamics following afforestation of degraded pastures with eucalyptus in Southeastern Brazil. For. Ecol. Manag. 2006, 235, 219-231. [CrossRef]

29. Barreto, P.A.B.; Gama-Rodrigues, A.C.; Gama-Rodrigues, E.F.; Barros, N.F. Nitrogen balance in soil under eucalyptus plantations. Rev. Bras. Ciênc. Solo 2012, 36, 1239-1248. [CrossRef]

30. Friesen, D.K.; Rao, I.M.; Thomas, R.J.; Oberson, A.; Sanz, J.I. Phosphorus acquisition and cycling in crop and pasture systems in low fertility tropical soils. Plant Soil 1997, 196, 289-294. [CrossRef]

31. Araújo, M.S.B.; Schaefer, C.E.R.; Sampaio, E.V.S.B. Soil phosphorus fractions from toposequences of semi-arid Latosols and Luvisols in northeastern Brazil. Geoderma 2004, 119, 309-321. [CrossRef]

32. Beck, M.A.; Sanchez, P.A. Soil-phosphorus fraction dynamics during 18 years of cultivation on a typic paleudult. Soil Sci. Soc. Am. J. 1994, 58, 1424-1431. [CrossRef]

33. Tiessen, H. Phosphorus dynamics in tropical soils. In Phosphorus: Agriculture and the Environment, Agronomy Monograph; Sims, J.T., Sharpley, A.N., Eds.; SSSA: Madison, WI, USA, 2005; pp. 253-326.

34. Sales, M.V.S.; Gama-Rodrigues, A.C.; Comerford, N.B.; Cropper, W.P.; Gama-Rodrigues, E.F.; Oliveira, P.H.G. Respecification of structural equation models for the P cycle in tropical soils. Nutr. Cycl. Agroecosyst. 2015, 102, 347-358. [CrossRef]

35. Dieter, D.; Elsenbeer, H.; Turner, B.L. Phosphorus fractionation in lowland tropical rainforest soils in central Panama. Catena 2010, 2, 118-125. [CrossRef]

36. Xavier, F.A.S.; Almeida, E.F.; Cardoso, I.M.; Mendonca, E.S. Soil phosphorus distribution in sequentially extracted fractions in tropical coffee-agroecosystems in the Atlantic Forest biome, Southeastern Brazil. Nutr. Cycl. Agroecosyst. 2011, 89, 31-44. [CrossRef]

37. Turner, B.L. Organic phosphorus in Madagascan rice soils. Geoderma 2006, 136, 279-288. [CrossRef]

38. Oliveira, R.I.; Gama-Rodrigues, A.C.; Gama-Rodrigues, E.F.; Zaia, F.C.; Pereira, M.G.; Fontana, A. Organic phosphorus in diagnostic surface horizons of different Brazilian soil orders. Rev. Bras. Ciênc. Solo 2014, 38, 1411-1420. [CrossRef]

39. Schmitt, D.E.; Comin, J.J.; Gatiboni, L.C.; Tiecher, T.; Lorensini, F.; Melo, G.W.B.; Girotto, E.; Guardini, R.; Heinzen, J.; Brunetto, G. Phosphorus fractions in sandy soils of vineyards in southern Brazil. Rev. Bras. Ciênc. Solo 2013, 37, 472-481. [CrossRef]

40. Bellote, A.F.J.; Sarruge, J.R.; Haag, H.P.; Oliveira, G.D. Extração e exportação de nutriente pelo Eucalyptus grandis Hill ex-Maiden em função da idade: 1-Macronutrientes. IPEF Piracicaba 1980, 20, 1-23.

41. Poggiani, F.; Couto, H.T.Z.; Corradini, L.; Fazzio, E.C.M. Exportação de biomassa e nutrientes através da exploração dos troncos e das copas de um povoamento de Eucalyptus saligna. IPEF Piracicaba 1983, 25, 37-39.

42. Santana, R.C.; Barros, N.F.; Neves, J.C.L. Biomassa e conteúdo de nutrientes de procedências de Eucalyptus grandis e Eucalyptus saligna em alguns sítios florestais do Estado de São Paulo. Sci. For. 1999, 56, 155-169.

43. Santana, R.C.; Barros, N.F.; Novais, R.F.; Leite, H.G.; Comerford, N.B. Alocação de nutrientes em plantios de eucalipto no Brasil. Rev. Bras. Ciênc. Solo 2008, 32, 2723-2733. [CrossRef]

44. Laclau, J.P.; Deleporte, P.; Ranger, J.; Bouillet, J.P.; Kazotti, G. Nutrient dynamics throughout the rotation of Eucalyptus clonal stands in Congo. Ann. Bot. 2003, 91, 879-892. [CrossRef] [PubMed]

45. Silva, J.V.; Nogueira, G.S.; Santana, R.C.; Leite, H.G.; Oliveira, M.L.R.; Almado, R.P. Produção e acúmulo de nutrientes em povoamento de eucalipto em consequência da intensidade do desbaste e da fertilização. Pesq. Agropec. Bras. 2012, 47, 1555-1562. [CrossRef]

46. Gama-Rodrigues, A.C.; Barros, N.F. Ciclagem de nutrientes em floresta natural e plantios de eucalipto e de dandá no sudeste da Bahia, Brasil. Rev. Árvore 2002, 26, 193-207.

47. Gatiboni, L.C.; Kaminski, J.; Rheinheimer, D.S.; Flores, J.P.C. Biodisponibilidade de formas de fósforo acumuladas em solo sob sistema plantio direto. Rev. Bras. Ciênc. Solo 2007, 31, 691-699. [CrossRef]

48. Jones, D.L. Organic acids in the rhizosphere-A critical review. Plant Soil 1998, 205, 25-44. [CrossRef] 
49. Hinsinger, P. Bioavailability of soil inorganic $P$ in the rhizosphere as affected by root-induced chemical changes: A review. Plant Soil 2001, 237, 173-195. [CrossRef]

50. Celi, L.; Barberis, E. Abiotic stabilization of organic phosphorus in the environment. In Organic Phosphorus in the Environment; Turner, B.L., Frossard, E., Baldwin, D., Eds.; CABI Publishing: Wallingford, WI, USA, 2005; pp. 113-132.

51. Richardson, A.E.; Lynch, J.P.; Ryan, P.R.; Delhaize, E.; Smith, F.A.; Smith, S.E.; Harvey, P.R.; Ryan, M.H.; Veneklaas, E.J.; Lambers, H.; et al. Plant and microbial strategies to improve the phosphorus efficiency of agriculture. Plant Soil 2011, 349, 121-156. [CrossRef]

52. Guppy, C.N.; Menzies, N.W.; Moody, P.W.; Blamey, F.P.C. Competitive sorption reactions between phosphorus and organic matter in soil: A review. Aust. J Soil 2005, 43, 189-202. [CrossRef]

53. Lambers, H.; Raven, J.A.; Shaver, G.R.; Smith, S. Plant nutrient-acquisition strategies change with soil age. Trends Ecol. Evol. 2008, 23, 95-103. [CrossRef] [PubMed]

54. Lambers, H.; Brundrett, M.C.; Raven, J.A.; Hopper, S.D. Plant mineral nutrition in ancient landscapes: High plant species diversity on infertile soils is linked to functional diversity for nutritional strategies. Plant Soil 2010, 334, 11-31. [CrossRef]

55. Radersma, S.; Grierson, P. Phosphorus mobilization in agroforestry: Organic anions, phosphatase activity and phosphorus fractions in the rhizosphere. Plant Soil 2004, 259, 209-219. [CrossRef]

56. Grierson, P.F.; Adams, M.A. Plant species affect acid phosphatase, ergosterol and microbial $\mathrm{P}$ in a Jarrah (Eucalyptus marginata Donn ex Sm.) forest in south-western Australia. Soil Bio. Biochem. 2000, 32, 1817-1927. [CrossRef]

57. Vitousek, P.M.; Porder, S.; Houlton, B.Z.; Chadwick, O.A. Terrestrial phosphorus limitation: Mechanisms, implications, and nitrogen-phosphorus interactions. Ecol. Appl. 2010, 20, 5-15. [CrossRef] [PubMed]

58. Zou, X.; Binkley, D.; Caldwell, B.A. Effects of dinitrogen-fixing trees on phosphorus biogeochemical cycling in contrasting forests. Soil Sci. Soc. Am. J. 1995, 59, 1452-1458. [CrossRef]

59. Barto, E.K.; Alt, F.; Oelmann, Y.; Wilcke, W.; Rillig, M. Contributions of biotic and abiotic factors to soil aggregation across a land use gradient. Soil Biol. Biochem. 2010, 42, 2316-2324. [CrossRef]

(C) 2016 by the authors; licensee MDPI, Basel, Switzerland. This article is an open access article distributed under the terms and conditions of the Creative Commons by Attribution (CC-BY) license (http://creativecommons.org/licenses/by/4.0/). 